Agnieszka Helman-Ważny, Liubov Kriakina, Alexander Zorin

\title{
The First Tibetan Leaves Acquired \\ by the St. Petersburg Academy of Sciences: Conservation Issues, Contents and Paper Analysis*
}

\begin{abstract}
The paper presents the first results of the study of 204 folios from the legendary Ablaikit monastery recently identified within the IOM, RAS Tibetan collection. The three main aspects touched upon are 1) the condition of the folios and the conservation treatment applied to make the study of their contents possible, 2) identification of texts that turned out to be fragments of an independent version of the Tibetan Buddhist canon, and 3) paper analysis.

Key words: conservation of Oriental texts, history of Tibetan paper, Tibetan thing shog manuscripts, Tibetan Buddhist Canon, Ablaikit monastery
\end{abstract}

In 2012-15, a number of rolled decorated folios were identified among the unprocessed materials held in the Tibetan collection of the IOM, RAS. These book leaves originated from the two Dzungar monasteries discovered by Russian soldiers along the Irtysh river in southern Siberia ${ }^{1}$ in $1717-21$. The study of their history ${ }^{2}$ showed that some of them, with blue margins and gold letters, were acquired first, perhaps, in 1718 from the Sem Palat Monastery, while the greater portion of the leaves, with dark violet margins and silver and gold letters, were sent to the Russian capital by two members of the St. Petersburg Academy of Sciences, Gerhard Friedrich Müller (1705-1783) and Johann Georg Gmelin (1709-1755), from Ablaikit Monastery in 1734³.

(C) Agnieszka Helman-Ważny, University of Hamburg, Asia-Africa Institute

(C) Liubov Ivanovna Kriakina, Institute of Oriental Manuscripts, Russian Academy of Sciences

(C) Alexander Valerievich Zorin, Institute of Oriental Manuscripts, Russian Academy of Sciences

* The study was supported by the Russian Foundation for Basic Research, project No. 1406-00460.

${ }^{1}$ It is now the territory of East Kazakhstan Province in the Republic of Kazakhstan.

${ }^{2}$ ZORIN forthcoming.

${ }^{3}$ The first batch of six leaves from the Ablaikit library was sent to St. Petersburg in 1721 and one of them must have been reproduced in Leipzig in 1722 ([MENCKE?] 1722) and then sent to Paris where É. and M. Fourmont attempted its translation (W ALRAVENS 2008, 150 
After all the calamities of the 1930s and 1940s, the folios were effectively lost within the Institute's huge Tibetan collection, especially after it was enlarged by several thousand texts brought to Leningrad from closed and destroyed Buryat Buddhist monasteries in the late 1930s. Later, during the 1960s and 1970s, the Tibetan collection was in the main sorted out by Margarita Vorobiova-Desiatovskaya, Lev Savitsky and Elena Ogneva but these materials remained among the scattered items until their re-discovery in 2012. They were found in several locations. Most were being kept rolled up, while the remainder were arranged in three piles placed between sheets of thick cardboard, possibly by Lev Savitsky, the curator of the Tibetan collection in the years 1969-2004. Unfortunately, this measure proved far from sufficient to return the damaged leaves to a usable condition. In fact, all the leaves, both rolled and slightly flattened, needed urgent conservation due to numerous defects and great fragility. This work started in 2014.

The paper of the folios turned out to be very dry and brittle; their edges, being the most vulnerable parts, were especially fragile and seriously deformed from the rolling; the numerous cracks, small losses of paper, flaws and dirty spots, through and incomplete splits, flaking of golden paint and ink layers, erosions of text, faded paper dye along the outer part of leaves, breaks and exfoliations in the paper were clearly visible, the traces of the holes made by the larva of bark beetles were noticed.

During initial conservation treatment, first a general dry cleaning of the paper, consisting of the removal of dust with a soft brush and of bird droppings with a scalpel, was undertaken. The most seriously soiled places were cleaned with a non-abrasive rubber eraser and a special Wishab sponge. Spots of pastose flows were cleaned with a cotton wool tampon barely moistened with a 1:1 water-alcohol solution (Pl. 1).

A test on dye flow by the application method gave a positive result, showing that the folios would be harmed if processed with water. We then employed a method of indirect moistening using special membranous materials such as Gore-tex and Bondina, which are recommended for the delicate moistening of paper objects sensitive to water. This method produced good results. Moreover, it allowed us to return the lost hydro component to the paper pulp, making it more flexible, thanks to which paper could be flattened more evenly, without any new losses or splits. Each folio was put on technical textile and covered with a sheet of Gore-tex, several

152). The other five folios may be at the British Library, under the shelf number Sloane 2837. They could have been left in London by J.D. Schumacher (1690-1761) in early 1722 (SCHIEFNER 1864, 44-45) but this still needs to be ascertained. 

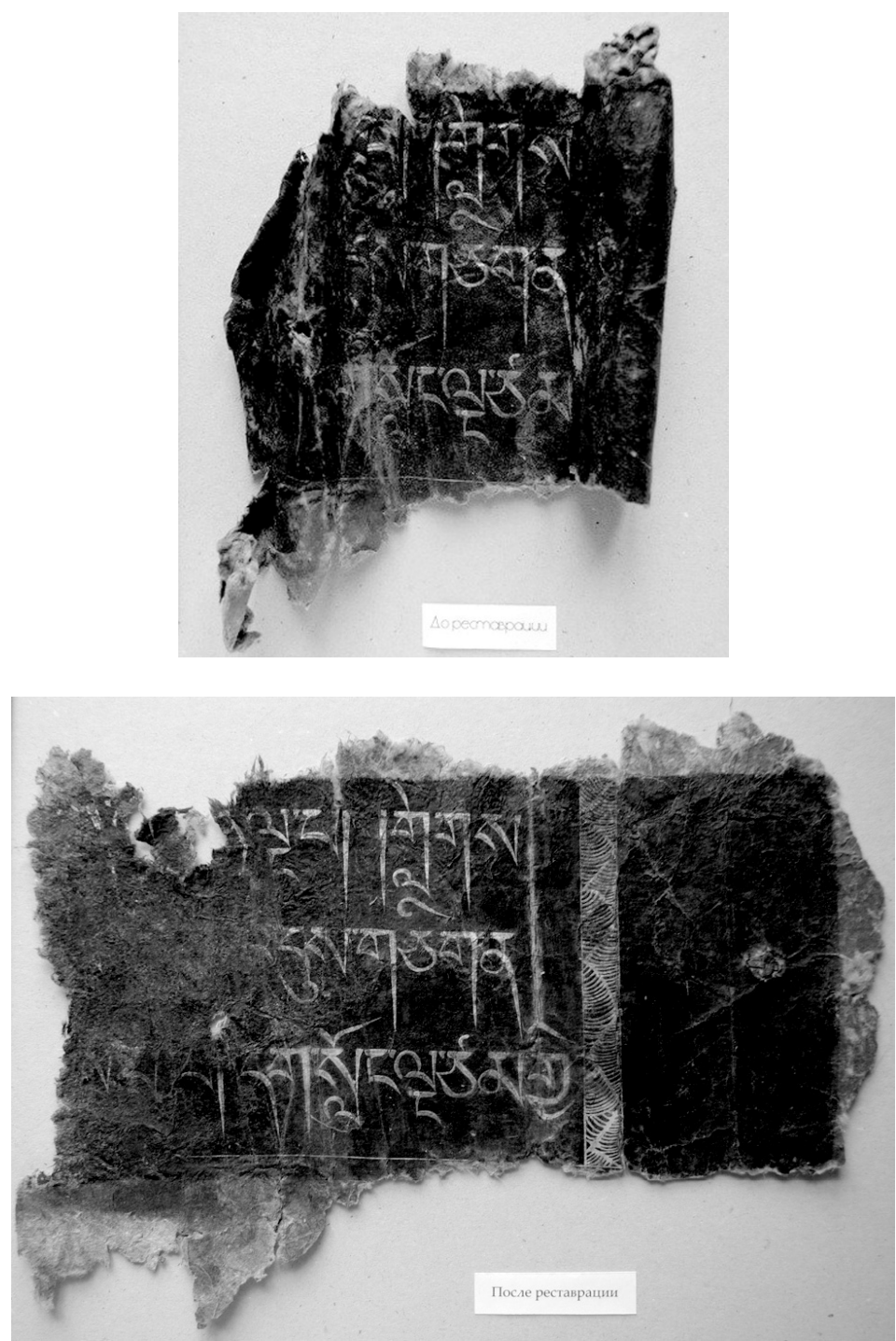

Pl. 1. One of the fragments: before and after conservation treatment

sheets of moistened filter paper, a layer of polyester film, and a layer of plywood beneath a weight. The level of moisturizing, with liquid from the filter paper, remained under control. After the folios were flattened and moistened, they were kept between two layers of technical textiles to complete the drying process and remove deformation. 
To restore aesthetic unity and structural integrity to the leaves the special paper inserts and reinforcements were applied together with wheat paste $(3 \%$ to $7 \%$ ). Lost parts were replaced and tears reinforced with paper produced in Japan that was then painted to match the original colours with water-soluble dyes. The fragments of the most damaged folios were consolidated, but not reconstructed to original size.

Along with conservation treatment the folios were all numbered and contents of each folio identified (the RKTS and, in few cases, TBRC search tools were used). ${ }^{4}$ There are 237 unique folios all together. Most of them are complete but a number were found to be in fragments, some rather small. The folios consist of two groups:

1) 33 ff. on blue paper with golden writing originated from Sem Palat. They consist of two subgroups of folios ${ }^{5}$ belonging to two different copies of a four-volume set of the Prajñāpāramitā Sütra in 25,000 stanzas;

2) $204 \mathrm{ff}$. on paper with dark violet margins and silver or/and gold writings originated from Ablaikit. They belong to various volumes from the set of an unknown edition of the Tibetan Buddhist Canon. ${ }^{6}$ A few other leaves found in various European repositories ${ }^{7}$ belong to this same work.

The following analysis deals only with the Ablaikit materials although some aspects of it are true for both groups of texts.

The Ablaikit library certainly had the entire first part of the Tibetan Buddhist Canon, the Kagyur. The second part, the Tengyur, could also have been present there, at least partially. The bulk of the $204 \mathrm{ff}$. kept at the IOM, RAS are fragments of various texts from the six divisions of Kagyur:

\footnotetext{
${ }^{4}$ Marginalia to the left of the text on the recto contain the numbers of the volumes (indicated with Tibetan letters) and folio numbers, no brief names of the sections or other titles are provided.

${ }^{5}$ The shelf numbers at the IOM, RAS - Tib.957 and Tib.958.

${ }^{6}$ The shelf number at the IOM, RAS is Tib.959.

${ }^{7}$ The following are known so far: National Library of Russia, St. Petersburg, 3 items two are found under No. 857 in DoRN 1852, the third in the fund 390, inv. 1, unit 80, all three identified by A. Zorin in 2014; British Library, London, 5 items - Sloane 2837a-e, information provided by S. van Schaik; Herzog August Library, Wolfenbüttel, Germany, 2 items Cod. Guelf. 9 Extra v IV and V, see HeISSIG 1979, KNÜPPEL 2014; Library of Kassel University, 1 item - Ms. orient. Anhang 4 [1, see KNÜPPEL 2014; Linköping City Library, 1 item Ol 4, information provided by M. von Wachenfeldt; Berlin State Library, 1 item, information provided by K.V. Alekseev and A.A. Turanskaya. There are also eight Tibetan and Mongolian folios in the National Library of France, Paris, including the most famous one reproduced in [MENCKE?] 1722, see ABEL-RÉmuSAT 1820, 332, n. 1; MXT, 41, No. 464.
} 
1) Vinaya $-60 \mathrm{ff}^{8}$

2) Prajñāpāramitā $-46 \mathrm{ff}^{9}$

3) Avatamsaka $-6 \mathrm{ff}^{10}$

4) Ratnakūta - $13 \mathrm{ff}^{11}$

5) Sütra $-33 \mathrm{ff}$.

6) Tantra $-41 \mathrm{ff}$.

The comparison of the order of texts in the Ablaikit Kagyur Sütra and Tantra sections with that in other editions shows no exact or close parallels (see the Appendix). It seems that there are similarities with the latest Lhasa edition (1934), especially in Tantra section, yet the difference is still too great. Apparently, we are dealing here with an independent version of the canon. ${ }^{12}$

The remaining five folios from three different volumes seem to belong to a Tengyur. The following texts are represented:

1) Rang gi lta ba'i 'dod pa mdor bstan pa yongs su brtag pa zhes bya ba (vol. ka?) by Mañjuśrivvarman, from the Rgyud 'grel section in the later xylographic editions of the Tengyur,

2) Sa bcu pa'i rnam par bshad pa (2 ff., vol. ma) by Vasubandhu, from the Mdo 'grel section;

3) Rgyu gdags pa (vol. za) ascribed to Maudgalyāyana, from the Mngon pa section;

4) 'Jig rten gzhag pa (vol. za) ascribed to Maudgalyāyana, from the Mngon pa section.

The Kagyur editions of the Them spangs ma group also contain Rgyu gdags pa and 'Jig rten gzhag pa but the Ablaikit Kagyur seems to be very different from them, hence there are more chances they were a part of the

\footnotetext{
${ }^{8}$ The following texts are represented: 'Dul ba gzhi (vols. ka-nga), 'Dul ba rnam par 'byed pa (vols. ca-nya), Dge slong ma'i 'dul ba rnam par 'byed pa (vol. nya), 'Dul ba phran tshegs kyi gzhi (vols. ta, tha), 'Dul ba gzhung dam pa (vol. da, a), 'Dul ba gzhung bla ma (vol. a).

${ }^{9}$ The following texts are represented: Prajñapāramitā Sūtra in 100,000 stanzas (vols. kada), Prajñāpāramitā Sütra in 25,000 stanzas (vol. kha), Prajñāpāramitā Sütra in 18,000 stanzas (vols. ka, kha), 'Phags pa rab kyi rtsal gyis rnam par gnon pas zhus pa shes rab kyi pha rol tu phyin pa bstan pa (vol. pha?).

${ }^{10}$ Folios from vols. kha, ga(?), nga and ca are found.

${ }^{11}$ Folios from vols. ka, kha, ga and nga are found.

${ }^{12}$ All known editions of the Kagyur are divided into five groups: Tshal pa group, Them spangs ma group, Mustang group (scarcely represented), mixed and independent editions. We would suggest that the Ablaikit edition can be included in the last category, joining the Phugbrag, Bhatang, Dolpo and Tawang Kagyurs (for details check the RKTS web resource). A deeper textual study of the fragments of the Ablaikit Kagyur is certainly needed to back up this statement.
} 
Ablaikit Tengyur. In any case, the first two texts in the list can hardly be expected to be found in any edition of the Kagyur so at least some volumes from a Tengyur must have been kept at Ablaikit. ${ }^{13}$

The technique of writing in gold or/and silver on a decorated background employed in the preserved manuscripts from Ablaikit monastery suggests that they belong to the deluxe editions of canonical texts called in Tibetan thing shog (referring to blue-black paper). Such luxurious productions would often be commissioned by a patron for a family or shrine, or as a gift to a monastery. The most common texts chosen for this technique were the Prajñāpāramitā Sütras, but often entire Kagyur sets were produced. The distinct practice of writing Tibetan manuscripts in gold on a dark background and embellishing them with precious stones began during the period known as the Tibetan Renaissance (spanning the 10th to 13th cc.), but this technique was known earlier in other book cultures as well. During the production of such decorative manuscripts, sheets of paper were cut down to the appropriate size, glued in a number of layers in order to create an adequately thick leaf, then processed on the surface to provide a good background for writing and painting. After the general layout of the page was planned (e.g., number of text lines, frames/borders, circles, initial signs), the page was lightly ruled with a sharp, pointed stick or wooden colouring stick, and the scribe set to work with an ink-pot and reed pen to execute the text.

Writing in gold involved the use of powdered gold mixed with a binding material to create an ink that was usually burnished when dry. The traditional production of thing shog paper involves a range of specific products, such as paper (shog bu), brains (glad pa), yak-hide glue (phing) and soot. ${ }^{14}$ However, we do not know when and where exactly Tibetans started to use such peculiar ingredients. In fact, there are many varieties of both materials and techniques used for this luxurious type of manuscript, which are preserved within Tibetan books written in gold in many library and museum collections. According to Jim Canary, who has recently made a study of the Tibetan craftsmen's technique, for preparing the black mixture a paste of yak, sheep or goat brains with very fine black powdered soot and a small amount of cooked hide glue is kneaded. ${ }^{15}$ He points to the fact that if there is too much brain material the paper will have an oiliness that will resist the writing and can also develop saponification problems, resulting in a white,

\footnotetext{
${ }^{13}$ One of the leaves (from vol. pa) kept at the British Library with the shelf number Sloane $2837 \mathrm{e}$ may also belong to the Tengyur but this has yet to be checked.

${ }^{14}$ CANARY 2014, 109.

${ }^{15}$ CANARY 2014, 109.
} 


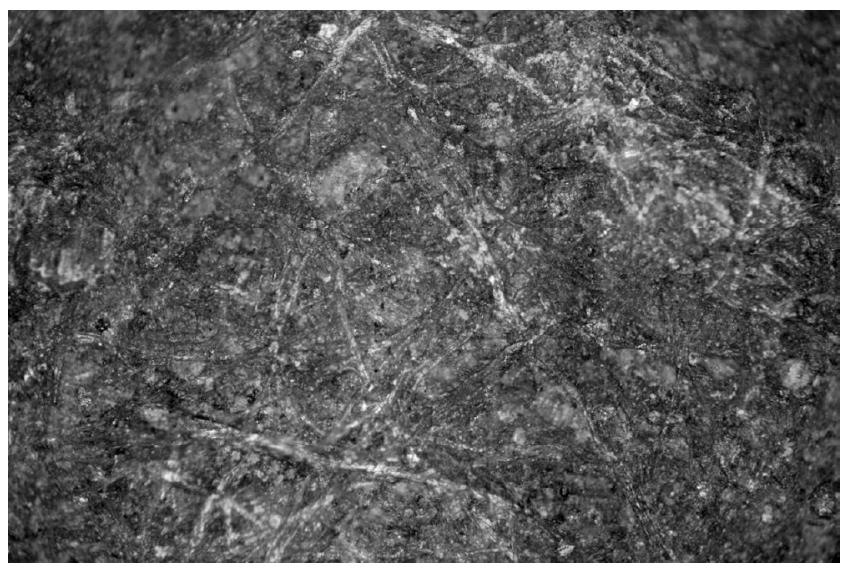

P1. 2. Surface of paper painted with diluted dark violet or brown paint in $200 \times$ magnification (sample 1).

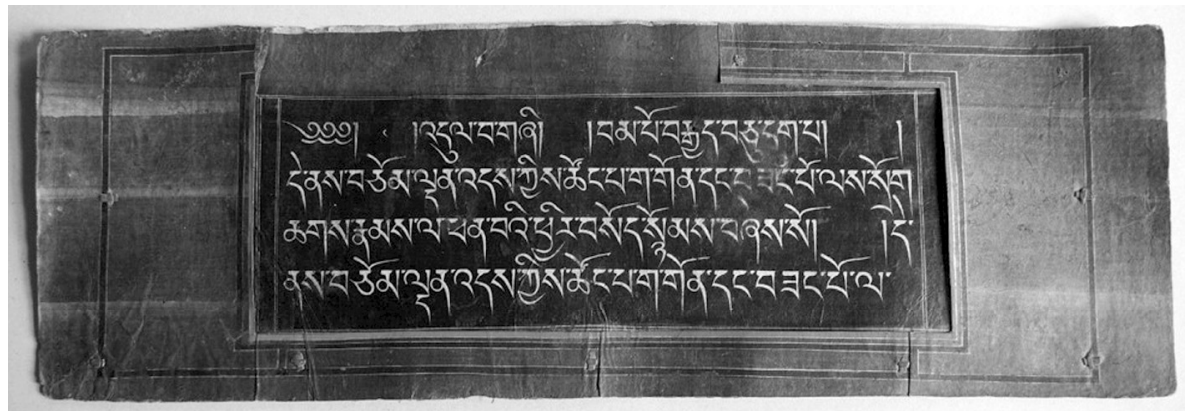

Pl. 3. F. 2 recto from the 4th volume of the Vinaya section, Ablaikit Kagyur (after initial conservation)

soapy bloom on the surface. This mixture is painted on the surface and left to dry. Then the surface is burnished ( $d b u r b a$ ) with a smooth piece of conch shell or a $g z i$ stone. Both the specific ingredients and burnishing process turn the matte surface into a beautiful shining support for writing in gold.

The Ablaikit folios are of large format, about $19 \times 62.5$ (text area $14 \times 57) \mathrm{cm}$. All have a black part in the central area of each page, intended as a foundation for the text, with blue or black coloured borders. Some of the folios have been burnished like lacquer sheets, which is a distinguishing feature of this technique. All of them have dark violet or brownish borders, probably painted on the surface with diluted ink with the possible addition of brown paint (Pl. 2). 
Some folios have small "clips" - narrow strips of brownish red paper which join several paper layers together, having both a decorative and structural function. Thicker folios with this feature, often placed at the beginning of the book or book section, serve as a kind of inner cover (and title page). ${ }^{16}$ For example, folio 2 from one of the volumes of the Vinaya section is made up of three layers of thick paper and has a dark blue passepartout that is not glued to the other layers along its inner perimeter. It is clear, then, that in this case the "clips" are a structural element fastening the layers of the thick leaf together (Pl. 3). The rectangular frame, composed of red and black lines edged with thin golden lines, is a purely decorative element here. On the right side, beneath the passe-partout, there is a fragment of untwisted yellow silk thread. On the verso side of the folio, we can see rather careless traces of the brush with which the black background for the text was applied. Some folios have appliqués of white or grey paper bearing stūpa images painted bright yellow, lemon red, bright vermillion red or pink.

Scribal base lines can be dimly seen on some folios. The binding places, symbolic rather than actual, are marked with characteristic double circles. This is a common feature of Tibetan manuscript layout: circles located exactly in the places where holes would have been pierced for stringing pages together in the Indian pustaka. These circles were primary to the layout of the text. First, frames, side margins, and circles were sketched, and then text was inscribed. These circles are found in many Tibetan books such as the Tibetan manuscripts from Dunhuang, the Tibetan Sel dkar Kagyur from the British Library, and gold manuscripts in the Columbia University Library. ${ }^{17}$ There are a variety of forms, such as one or two circular shapes sketched by a sharp tool, often redrawn multicoloured with gold, red or silver ink. Some of these circles are also richly decorated with ornaments and even gems. In rare instances these circles can even be found in early prints from Central Tibet.

The materials composing ink and paints require further analysis, but we can assume that lamp-black was used here. Black ink in Tibet is usually made of carbonized plants or oil soot with yak hide glue. The most essential ingredient for Tibetan black ink (nagtsha, snag tsha) is the soot of burned pine trees (Pinus wallichiana) or sometimes the soot from burning oil (num, snum). Traditionally, a boiled solution of animal glue allowed to cool and congeal was added to soot. ${ }^{18}$ This solution was repeatedly pressed in a

\footnotetext{
${ }^{16}$ PAKHOUTOVA and HeLMAN-W AŻNY 2012, 125.

${ }^{17}$ HELMAN-WAŻNY 2014, 86-88.

${ }^{18}$ RicCIARDI and PALLIPURATH 2014, 105.
} 
leather bag, and then water was gradually added. After the solution had been mixed and dried, it was ground to a powder, sometimes with the addition of mica. ${ }^{19}$ However, it could also contain other organic components that modified its properties to meet particular needs. Various recipes for its preparation include soot from burnt resinous wood or butter lamps, other pigments, or metal as the ink's main components, with the possible admixture of gum, honey, borax or, for some special occasion, other unusual and extravagant materials. Soot would be collected from the interiors of stacked bottomless clay pots after selected components were burned at the bottom of the vessels.

Paper analysis was performed on one sample that cannot be ascribed to any particular folio but was taken from numerous tiny fragments easily separating from the fragile edges. We assume that this analysis can be taken to apply to all the Ablaikit folios, given their evident close similarity, but to be sure some more tests of random samples are to be made later.

The paper sample No. 1 shows the presence of two types of fibre belonging to the Thymelaeaceae family: Edgeworthia/Daphne sp. mixed with a small addition of Stellera chamaejasme fibres. Fibres of the first type were generally narrower and more rigid. The broad portions were not associated with cross-markings, which occurred densely and were often visible as a ' $v$ ' or zigzag shape in polarized light. Dislocations and irregularities in the fibrethick walls and narrow-lumens stained pinkish with Herzberg were clearly visible. This type may be one of two species - Edgeworthia sp. or Daphne $s p$., both belonging to the Thymelaeaceae family. It was very difficult to tell these two species apart, but they can at least be distinguished from the second type by observing the shape and size of fibres. Both species were used as the basic materials in papers originating from the foothills of the Himalayas. Fibres of the second type were wider, flat, and presented a very wide lumen and narrow fibre walls. (Pl. 4) Ribbon-like fibre placement and significant irregularities in fibre length make it possible to identify this type as Stellera chamaejasme, which is distinctive among the range of fibres found in historical papers and can be clearly differentiated from Daphne and Edgeworthia despite the fact that all three plants belong to the Thymelaeaceae family. (Pl. 5)

The fibre composition of the sample examined suggests that this paper was produced in Tibet. Similarly composed original Tibetan paper was made mainly from the phloem of shrubs belonging to the Daphne and Edgeworthia

\footnotetext{
${ }^{19}$ CÜPPERS 1989.
} 


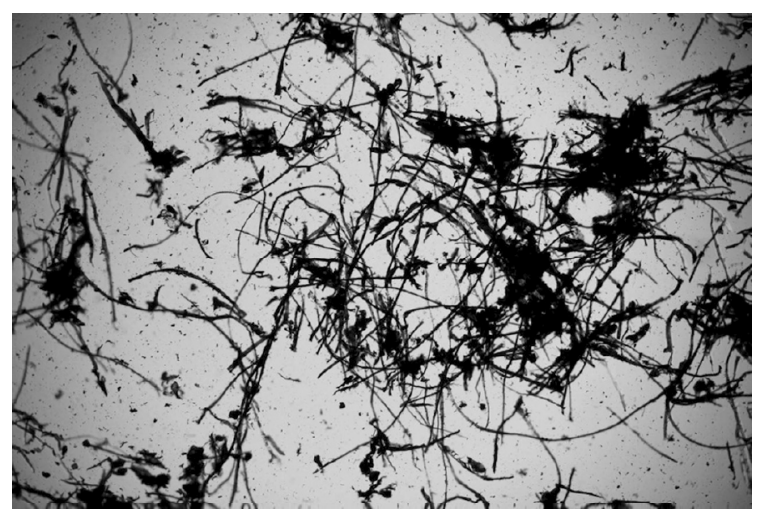

P1. 4. Edgeworthia/Daphne sp. fibres with addition of Stellera chameajasme fibres stained olive-grey/greenish with Herzberg at $100 \times$ magnification.

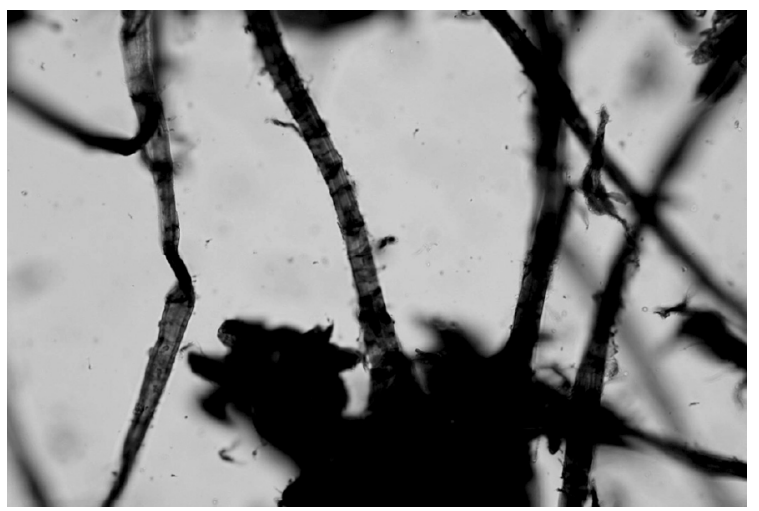

Pl. 5. Edgeworthia/Daphne sp. and Stellera chameajasme fibres (on the left) stained olive-grey/greenish with Herzberg at $400 \times$ magnification.

The narrow lumen with some broad portions in the Edgeworthia/Daphne fibre (in the middle) and very wide lumen and thin fibre walls on the Stellera fibre on the left are clearly visible in the above photograph.

species (shog shing in Tibetan) by the 9th century and the roots of the Stellera chamaejasme species (re lcag pa in Tibetan) by the 10th century in Central Tibet. We cannot date the folios from Ablaikit, ${ }^{20}$ however, we can

${ }^{20}$ It is clear they must have been produced before 1671 when Ablaikit was left by its founder, the Dzungar chieftain Ablai, and it was destined to oblivion. We can also speculate that the canon could be obtained in connection with the visit of the famous Oirat teacher and translator Zaya Pandita (1599-1662) who consecrated Ablaikit in 1657 (BORODAEV and KONTEV 1999). 
recognize some general indications on the regional origin of paper production, since the usage of particular raw materials is strongly dependent on geographical region. The altitude range of Daphne sp. extends to 3,600 m above sea level, while Stellera sp. is widely distributed across the Himalayan range at altitudes of 2,700 to 4,500 m. Additionally Daphne plants need much more moisture than Stellera. Thus, these two species very rarely grow in the same habitat. Preliminary research shows that the Stellera root fibres are confirmed as a dominant component in manuscripts from both Central and Western Tibet. However, we should undertake further research to see if other features of the Ablaikit leaves correspond to their paper support.

The main conclusions of our research can be listed as follows.

In spite of high fragility and numerous defects of the manuscripts that were kept for about three centuries without any special treatment, initial conservation using the method of remote moistening proved rather effective in returning them to academic and cultural spheres.

The 204 manuscripts folios from Ablaikit monastery are fragments from various volumes of a set of the Tibetan Buddhist Canon. The bulk of them, $199 \mathrm{ff}$., represent an independent edition of the Kagyur, while the other five (or at least three) indicate that an entire Tengyur, or some volumes of one, was also kept at Ablaikit.

The manuscripts belong to the deluxe editions of canonical texts called in Tibetan thing shog (referring to blue-black paper) and so they must have been produced to a special commission from some patron who could finance such a costly project.

The paper sample shows the presence of two types of Thymelaeaceae family fibres: Edgeworthia/Daphne sp. mixed with a small amount of Stellera chamaejasme fibres. This supports a hypothesis of a Central or Western Tibetan origin for the manuscripts.

\section{References}

ABEL-RÉMUSAT, Jean-Pierre 1820: Recherches sur les langues tartares, t. I. Paris: De l'Imprimerie royale.

BORODAEV V.B. and KONTEV A.V. 1999: "Monastyr Ablai-khit kak pamiatnik sotsialno-politicheskoi istorii oiratov XVII v." [The Ablaikit monastery as a monument of the social-political history of the Oirats from the 17th c.]. Rossiya, Sibir $i$ Tsentral'naia Aziia (vzaimodeistvie narodov i kultur). Materialy II regional'noi konferentsii 26 oktiabria $1999 \mathrm{~g}$. [Russia, Siberia and Central Asia (Interactions between peoples and cultures). Proceedings of the 2nd Regional Conference, 26 October 1999]. Barnaul: Izdatelstvo BGPU, 12-22. 
72

CANARY, James 2014: "Thingshog (mthing shog): Luxury Illuminated Manuscripts on Blueblack Paper". Buddha's Words. The Life of Books in Tibet and Beyond. Ed. by Mark Elliot, Hildegard Diemberger and Michela Clemente. Cambridge: Museum of Archaeology and Anthropology, 109-110.

CÜPPERS, Christoph 1989: "On the Manufacture of Ink”. Ancient Nepal 113, 8-9.

DORN, Johannes Albrecht Bernhard (Boris Andreevich) 1852: Catalogue des manuscrits et xylographes orientaux de la Bibliothèque impériale publique de St.-Pétersbourg. St.Pétersbourg: Imprimerie de l'Académie impériale des sciences.

HeIssig, Walther 1979: "Die erste mongolische Handschrift in Deutschland". Zentralasiatische Studien 13, 191-214.

HeLman-W AŻ̀n, Agnieszka 2014: The Archaeology of Tibetan Books. Leiden, Boston: Brill.

KNÜPPEL, Michael 2014: Vom Irtysch nach Kassel. Zum Problem der ersten mongolischen und tibetischen Handschriften in Deutschland. Kassel: Kassel University Press.

[MENCKE?], Johann Burckhardt 1722: "Nova literaria de msptis codicibus in Tartaria repertis". Acta eruditorum. Lipsiae [Leipzig], 374-376.

MXT: "Manuscrits et xylographes tibétains". Inventaire sommaire des fonds divers orientaux. Paris: Bibliothèque nationale de France, $39 \mathrm{v}-56$.

Pakhoutova, Elena and Helman-W AŻNY, Agnieszka 2012: "Tools of Persuasion: The Art of Sacred Books". Orientations Magazine 43(2), 124-129.

Ricciardi, Paola and PAllipurath, Anuradha 2014: "Colours". Buddha's Words. The Life of Books in Tibet and Beyond. Ed. by Mark Elliot, Hildegard Diemberger and Michela Clemente. Cambridge: Museum of Archaeology and Anthropology, 103-105.

SCHIEFNER, Franz Anton (Anton Antonovich) 1868: "Bericht über eine Reise nach England im Sommer 1863". Mélanges asiatiques 5. St.-Pétersbourg, 41-48.

WalraVens, Hartmut 2008: "Some Notes on Early Tibetan Studies in Europe". Images of Tibet in the 19th and 20th Centuries. Textes réunis et présentés par Monica Esposito. Paris: École française d'Extrême-Orient, collection «Etudes thématiques» 22(1), 149-176.

ZORIN A.V. (forthcoming): "The History of the First Tibetan Texts Acquired by the St. Petersburg Academy of Sciences in the 18th c.". Journal of the International College for Postgraduate Buddhist Studies 19.

\section{Electronic resources}

RKTS: Resources for Kanjur and Tanjur Studies; https://www.istb.univie.ac.at/kanjur/ $\mathrm{xml} / \mathrm{xml} /$

TBRC: Tibetan Buddhist Research Center; http://www.tbrc.org 


\section{Appendix}

To compare the structure of the Ablaikit Kagyur, which can only be reconstructed in a very limited way due to the small number of folios known, we compiled a list of concordances between the Ablaikit manuscripts and all the Kagyur editions represented on the RKTS web resource. We did this only for the Sütra and Tantra sections since the other sections are fairly standard and do not vary much in structure.

The two tables presented below are reduced versions of the full ones since the order of the texts in the two basic groups proved almost identical while the mixed Lhasa and Narthang editions also have much in common. Two independent editions, Phugbrag and Dolpo, turned out to be totally different from the Ablaikit Kagyur so their data are omitted here. All the other editions seem to be too scarce to be included, either.

The first column of the tables contains the access numbers at the IOM, RAS (from Tib. 959, No. 113 to Tib. 959, No. 174 and from Tib. 959, No. 193 to Tib. 959, No. $204^{21}$ ), the second the folio marginalia if legible, the third the standard Tibetan titles as provided by the RKTS. In addition to the manuscripts kept at the IOM, RAS we used the texts of three leaves from the same set found at other libraries in Europe (see footnotes). Those entries are marked with italics.

\section{Sütra Section}

\begin{tabular}{|l|l|l|l|l|l|}
\hline $\begin{array}{c}\text { Tib.959 } \\
\text { No. }\end{array}$ & $\begin{array}{c}\text { Folio } \\
\text { No. }\end{array}$ & \multicolumn{1}{|c|}{ Tibetan title } & $\begin{array}{c}\text { Vol. in } \\
\text { Tshal pa } \\
\text { group }\end{array}$ & $\begin{array}{c}\text { Vol. in } \\
\text { Them } \\
\text { spangs } \\
\text { ma group }\end{array}$ & $\begin{array}{c}\text { Vol. in } \\
\text { Lhasa / } \\
\text { Narthang } \\
\text { eds. }\end{array}$ \\
\hline $113-115$ & $\begin{array}{l}\text { Ka, 295 } \\
\text { Ka, 306 } \\
\text { Ka, 413 } \\
\text { Ka, 19 } \\
\text { Ka, 122 } \\
\text { Ka, 183 } \\
\text { Ka, 268 }\end{array}$ & $\begin{array}{l}\text { 'Phags pa bskal pa bzang po zhes } \\
\text { bya ba theg pa chen po'i mdo }\end{array}$ & ka & ka & ka / ka \\
\hline 197 & Kha, 11 & $\begin{array}{l}\text { 'Phags pa rgya cher rol pa zhes bya } \\
\text { ba theg pa chen po'i mdo }\end{array}$ & kha & kha & kha / kha \\
\hline 198 & Ga?, 19 & $\begin{array}{l}\text { 'Phags pa lang kar gshegs pa'i theg } \\
\text { pa chen po'i mdo }\end{array}$ & ca & da & ca / ca \\
\hline 116 & Nga, 207 & $\begin{array}{l}\text { 'Phags pa khye'u snang ba bsam } \\
\text { gyis mi khyab pas bstan pa zhes bya } \\
\text { ba'i chos kyi rnam grangs }\end{array}$ & nga & ta & nga / nga \\
\hline 117 & $?, 1(?) 37$ & $\begin{array}{l}\text { 'Phags pa dgongs pa nges par 'grel } \\
\text { pa zhes bya ba theg pa chen po'i mdo }\end{array}$ & ca & na & ca / ca \\
\hline 118 & Ca, 325 & $\begin{array}{l}\text { 'Phags pa don rgyas pa zhes bya } \\
\text { ba'i chos kyi rnam grangs }\end{array}$ & sa & dza & la / la \\
\hline
\end{tabular}

${ }^{21}$ Two rolls that contained 25 ff. were found in 2015, after the previously found folios had been already given their access numbers. 


\begin{tabular}{|c|c|c|c|c|c|}
\hline 199 & Cha, 36 & $\begin{array}{l}\text { 'Phags pa khye'u bzhi'i ting nge } \\
\text { 'dzin ces bya ba theg pa chen po'i } \\
\text { mdo }\end{array}$ & na & nya & tha / tha \\
\hline 119 & Cha, 221 & $\begin{array}{l}\text { 'Phags pa las kyi sgrib pa rgyun } \\
\text { gcod pa zhes bya ba theg pa chen } \\
\text { po'i mdo }\end{array}$ & tsha & nya & $\mathrm{ma} / \mathrm{ma}$ \\
\hline 120 & Cha, 259 & $\begin{array}{l}\text { 'Phags pa klu'i rgyal po rgya } \\
\text { mtshos zhus pa zhes bya ba theg pa } \\
\text { chen po'i mdo }\end{array}$ & pha & ba & na / na \\
\hline $121-122$ & $\begin{array}{l}\text { Nya, } 207 \\
\text { Nya, } 249\end{array}$ & $\begin{array}{l}\text { 'Phags pa dam pa'i chos dran pa } \\
\text { nye bar gzhag pa }\end{array}$ & ya & $\mathrm{ki}$ & $\mathrm{za} / \mathrm{za}$ \\
\hline 123 & $\mathrm{Na}, 4$ & $\begin{array}{l}\text { 'Phags pa blo gros rgya mtshos zhus } \\
\text { ba zhes bya ba theg pa chen po'i } \\
\text { mdo }\end{array}$ & pha & ba & na / na \\
\hline 124 & $\mathrm{Na}, 256$ & $\begin{array}{l}\text { 'Phags pa sangs rgyas kyi dbu rgyan } \\
\text { zhes bya ba theg pa chen po'i mdo } \\
\text { chos kyi rnam grangs chen po }\end{array}$ & ya & cha & $\mathrm{za} / \mathrm{za}$ \\
\hline $125-126$ & $\begin{array}{l}\text { Tsa, } 57 \\
\text { Tsa, } 67\end{array}$ & $\begin{array}{l}\text { 'Phags pa lang kar gshegs pa'i theg } \\
\text { pa chen po'i mdo } \\
\text { 'Phags pa lang kar gshegs pa'i theg } \\
\text { pa chen po'i mdo }\end{array}$ & $\mathrm{ca}$ & da & $\mathrm{ca} / \mathrm{ca}$ \\
\hline 200 & Tsa, 280 & $\begin{array}{l}\text { ltung ba sde lnga'i dge ba dang mi } \\
\text { dge ba'i 'bras bu brtag pa'i mdo }\end{array}$ & $\mathrm{sa}$ & chi & la / la \\
\hline 127 & Zha, 198 & $\begin{array}{l}\text { 'Phags pa 'dus pa chen po rin po } \\
\text { che tog gi gzungs zhes bya ba theg } \\
\text { pa chen po'i mdo }\end{array}$ & na & $\mathrm{ra}$ & tha / tha \\
\hline 128 & 'A, 115 & $\begin{array}{l}\text { Thabs mkhas pa chen po sangs } \\
\text { rgyas drin lan bsab pa'i mdo }\end{array}$ & ạ & wa & $\mathrm{a} / \mathrm{a}$ \\
\hline $129-130$ & $\begin{array}{l}\text { Ya, } 162 \\
\text { Ra, } 9\end{array}$ & $\begin{array}{l}\text { 'Phags pa yongs su mya ngan las } \\
\text { 'das pa chen po'i mdo }\end{array}$ & nya & $\mathrm{ka}$ & $\mathrm{ka}^{22}$ \\
\hline $131-132$ & $\begin{array}{l}\text { La, } 279 \\
\text { La, } 282\end{array}$ & Las brgya tham pa & ha & ha & sha / sha \\
\hline $133-134$ & $\begin{array}{l}\mathrm{A}, 16 \\
\mathrm{~A}, 27 \\
\end{array}$ & $\begin{array}{l}\text { 'Phags pa phung po gsum pa zhes } \\
\text { bya ba theg pa chen po'i mdo }\end{array}$ & ya & cha & $\mathrm{za} / \mathrm{za}$ \\
\hline 201 & A, 232 & $\begin{array}{l}\text { 'Phags pa chos thams cad kyi rang } \\
\text { bzhin mnyam pa nyid rnam par } \\
\text { spros pa ting nge 'dzin gyi rgyal po } \\
\text { zhes bya ba theg pa chen po'i mdo }\end{array}$ & da & ja & $\mathrm{ta} / \mathrm{ta}$ \\
\hline 202 & $?$ & $\begin{array}{l}\text { 'Phags pa sangs rgyas bgro ba zhes } \\
\text { bya ba theg pa chen po'i mdo }\end{array}$ & dza & cha & $\mathrm{a} / \mathrm{a}$ \\
\hline 135 & $?$ & Tshangs pa'i dra ba’i mdo & ah & cha & $\mathrm{a} / \mathrm{a}$ \\
\hline
\end{tabular}

${ }^{22}$ Here and in the Them spangs ma group this long Sütra is presented as a separate section briefly titled Myang 'das. 
Tantra Section

\begin{tabular}{|c|c|c|c|c|c|}
\hline $\begin{array}{l}\text { Tib.959 } \\
\text { No. }\end{array}$ & $\begin{array}{l}\text { Folio } \\
\text { No. }\end{array}$ & Tibetan title & $\begin{array}{l}\text { Vol. in } \\
\text { Tshal pa } \\
\text { group }\end{array}$ & \begin{tabular}{|c|} 
Vol. in \\
Them \\
spangs \\
ma group \\
\end{tabular} & \begin{tabular}{|c|} 
Vol. in \\
Lhasa / \\
Narthang \\
eds. \\
\end{tabular} \\
\hline 136 & $\mathrm{Ka}, 192$ & $\begin{array}{l}\text { Dpal sangs rgyas thams cad dang } \\
\text { mnyam par sbyor ba mkha' 'gro ma } \\
\text { sgyu ma bde ba'i mchog ces bya ba'i } \\
\text { rgyud bla ma }\end{array}$ & $\mathrm{ka}$ & $\begin{array}{l}\text { ka } \\
\text { (var. nga) }\end{array}$ & $\mathrm{ka} / \mathrm{ka}$ \\
\hline 203 & $\mathrm{Ka}, 230$ & $\begin{array}{l}\text { Dpal sangs rgyas thams cad dang } \\
\text { mnyam par sbyor ba mkha' 'gro ma } \\
\text { sgyu ma bde ba'i mchog ces bya ba'i } \\
\text { rgyud bla ma }\end{array}$ & $\mathrm{ka}$ & $\begin{array}{l}\text { ka } \\
\text { (var. nga) }\end{array}$ & $\mathrm{ka} / \mathrm{ka}$ \\
\hline 137 & Kha, 96 & $\begin{array}{l}\text { Rgyud kyi rgyal po chen po dpal rdo } \\
\text { rje mkha', gro zhes bya ba }\end{array}$ & kha & $\begin{array}{l}\text { ka } \\
\text { (var. kha) }\end{array}$ & kha / kha \\
\hline 138 & Ga, 84 & $\begin{array}{l}\text { Yang dag par sbyor ba zhes bya ba'i } \\
\text { rgyud chen po }\end{array}$ & ga & $\begin{array}{l}\text { ga } \\
\text { (var. kha) }\end{array}$ & ga / ga \\
\hline 139 & $\mathrm{Ca}, 111$ & $\begin{array}{l}\text { Dgongs pa lung bstan pa zhes bya ba'i } \\
\text { rgyud }\end{array}$ & $\mathrm{ca}$ & $\mathrm{ca}$ & $\mathrm{ca} / \mathrm{ca}$ \\
\hline 140 & $\mathrm{Ga}, 170$ & Dpal stobs po che'i rgyud kyi rgyal po & $\begin{array}{l}\text { nga } \\
\text { (var. ga) }\end{array}$ & $\begin{array}{l}\text { ka } \\
\text { (var. kha) }\end{array}$ & - \\
\hline 204 & $\mathrm{Ca}, 142$ & $\begin{array}{l}\text { Rnal 'byor chen po'i rgyud dpal rdo } \\
\text { rje phreng ba mngon par brjod pa } \\
\text { rgyud thams cad kyi snying po gsang } \\
\text { ba rnam par phye ba zhes bya ba }\end{array}$ & $\mathrm{ca}$ & ca & $\mathrm{ca} / \mathrm{ca}$ \\
\hline $141-143$ & $\begin{array}{l}\text { Cha, } 37 \\
\text { Cha, } 43 \\
\text { Cha, } 45\end{array}$ & $\begin{array}{l}\text { Rgyud kyi rgyal po chen po sgyu } \\
\text { 'phrul dra ba zhes bya ba }\end{array}$ & ja & cha & $\mathrm{ca} / \mathrm{cha}$ \\
\hline 144 & Cha, 123 & $\begin{array}{l}\text { Dpal gshin rje'i gshed dmar po zhes } \\
\text { bya ba'i rgyud kyi rgyal po }\end{array}$ & ja & cha & $\mathrm{ca} / \mathrm{ja}$ \\
\hline $145-147$ & $\begin{array}{l}\text { Cha, } 134 \\
\text { Cha, } 148 \\
\text { Cha, } 152 \\
\end{array}$ & $\begin{array}{l}\text { Dpal ldan gshin rje gshed dmar po'i } \\
\text { rgyud kyi rgyal po zhes bya ba }\end{array}$ & - & cha & $\mathrm{ca} /-$ \\
\hline $148-150$ & $\begin{array}{l}\mathrm{Ja}, 22 \\
\mathrm{Ja}, 105 \\
\mathrm{Ja}, 127\end{array}$ & $\begin{array}{l}\text { Gsang ba rnal 'byor chen po'i rgyud } \\
\text { rdo rje rtse mo }\end{array}$ & nya & ja & cha / nya \\
\hline 151 & Nya, 110 & $\begin{array}{l}\text { 'Phags pa gsang ba nor bu thig le zhes } \\
\text { bya ba'i mdo }\end{array}$ & tha & ta & nya / ta \\
\hline \multirow[t]{2}{*}{$152-153$} & $\begin{array}{l}\text { Nya, } 128 \\
\text { Nya, } 135\end{array}$ & $\begin{array}{l}\text { De bzhin gshegs pa thams cad kyi sku } \\
\text { dang gsung dang thugs kyi gsang ba } \\
\text { rgyan gyi bkod pa zhes bya ba'i rgyud } \\
\text { kyi rgyal po }\end{array}$ & $\begin{array}{l}\text { ta } \\
\text { (var. tha) }\end{array}$ & ta & ja / nya \\
\hline & $\begin{array}{l}\text { Nya, } ?^{23} \\
N y a, \\
188^{24}\end{array}$ & $\begin{array}{l}\text { Rnam par snang mdzad chen po mngon } \\
\text { par rdzogs par byang chub pa rnam } \\
\text { par sprul ba byin gyis rlob pa shin tu } \\
\text { rgyas pa mdo sde'i dbang po rgyal po } \\
\text { zhes bya ba'i chos kyi rnam grangs }\end{array}$ & tha & ta & nya / ta \\
\hline
\end{tabular}

\footnotetext{
${ }^{23}$ Cod. Guelf. 9 Extra v IV.
}

${ }^{24}$ [Mencke?] 1722. 


\begin{tabular}{|c|c|c|c|c|c|}
\hline $154-155$ & \begin{tabular}{|l|} 
Nya, 389 \\
Nya, 421
\end{tabular} & $\begin{array}{l}\text { 'Phags pa lag na rdo rje dbang bskur } \\
\text { ba'i rgyud chen po }\end{array}$ & da & tha & ta / tha \\
\hline $156-157$ & $\begin{array}{l}\text { Ta, } 141 \\
\text { Ta, } 147\end{array}$ & $\begin{array}{l}\text { Dam tshig gsum bkod pa'i rgyal po } \\
\text { zhes bya ba'i rgyud }\end{array}$ & da & tha & ta / tha \\
\hline 158 & Тa, 208 & $\begin{array}{l}\text { Dpa' bo gcig bu grub pa zhes bya ba'i } \\
\text { rgyud kyi rgyal po chen po }\end{array}$ & pa & da & tha / da \\
\hline 159 & Tha, 155 & $\begin{array}{l}\text { 'Phags pa 'jam dpal gyi rtsa ba'i } \\
\text { rgyud }\end{array}$ & na & da & tha / da \\
\hline 160 & Tha, 250 & $\begin{array}{l}\text { 'Phags pa gser 'od dam pa mchog tu } \\
\text { rnam par rgyal ba'i mdo sde'i rgyal } \\
\text { po zhes bya ba theg pa chen po'i mdo }\end{array}$ & pa & na & $\mathrm{da} / \mathrm{na}$ \\
\hline \multirow[t]{2}{*}{$161-164$} & $\begin{array}{l}\mathrm{Da}, ? \\
\mathrm{Da}, 68 \\
\mathrm{Da}, 91 \\
\mathrm{Da}, 96\end{array}$ & $\begin{array}{l}\text { 'Phagspagser } \\
\text { 'oddampamdosde'idbangpo'irgyalpoz } \\
\text { hesbyabathegpachenpo'imdo }\end{array}$ & pa & na & da / na \\
\hline & $D a, 118^{25}$ & $\begin{array}{l}\text { Kun nas sgor 'jug pa'i 'od zer gtsug } \\
\text { tor dri ma med par snang ba de bzhin } \\
\text { gshegs pa thams cad kyi snying po } \\
\text { dang dam tshig la rnam par lta ba } \\
\text { zhes bya ba'i gzungs }\end{array}$ & pha & pa & $\mathrm{na} / \mathrm{pa}$ \\
\hline 165 & $\mathrm{Da}, 286$ & $\begin{array}{l}\text { 'Phags pa de bzhin gshegs pa thams } \\
\text { cad kyi gtsug tor nas byung ba gdugs } \\
\text { dkar mo can zhes bya ba gzhan gyis } \\
\text { mi thub ma phyir zlog pa'i rig sngags } \\
\text { kyi rgyal mo chen mo }\end{array}$ & pha & pa & na/pa \\
\hline 166 & $\begin{array}{l}\mathrm{Da}, 332- \\
333\end{array}$ & $\begin{array}{l}\text { 'Phags pa 'od zer dri ma med pa rnam } \\
\text { par dag pa'i 'od ces bya ba'i gzungs }\end{array}$ & pha & $\mathrm{pa}$ & na / pa \\
\hline 167 & $\mathrm{Na}, 261$ & $\begin{array}{l}\text { 'Phags pa spyan ras gzigs dbang } \\
\text { phyug gi rtsa ba'i rgyud kyi rgyal po } \\
\text { pad ma dra ba zhes bya ba }\end{array}$ & $\mathrm{ba}$ & pha & $\mathrm{pa} / \mathrm{pha}$ \\
\hline 168 & $\mathrm{~Pa}, 285$ & $\begin{array}{l}\text { 'Phags pa don yod pa'i zhags pa'i cho } \\
\text { ga zhib mo'i rgyal po }\end{array}$ & $\mathrm{ma}$ & $\mathrm{ba}$ & $\begin{array}{l}\text { pha / ba } \\
(\text { 'og) }\end{array}$ \\
\hline 169 & $?, 106$ & $\begin{array}{l}\text { 'Phags pa rig pa mchog gi rgyud chen } \\
\text { po }\end{array}$ & $\begin{array}{l}\text { tsa } \\
\text { (var. dza) }\end{array}$ & tsa & $\mathrm{ba} / \mathrm{ma}$ \\
\hline 170 & Pha, 258 & $\begin{array}{l}\text { Ral pa gyen brdzes kyi rtog pa chen } \\
\text { po byang chub sems dpa' chen po'i } \\
\text { rnam par 'phrul pa le'u rab 'byams las } \\
\text { bcom ldan 'das ma 'phags ma sgrol } \\
\text { ma'i rtsa ba'i rtog pa zhes bya ba }\end{array}$ & - & ma & tsa \\
\hline 171 & A, 94 & $\begin{array}{l}\text { 1. Rdo rje mchu zhes bya ba klu'i } \\
\text { dam tshig } \\
\text { 2. Rdo rje gnam lcags mchu zhes bya } \\
\text { ba'i gzungs }\end{array}$ & $\begin{array}{l}\text { tsha } \\
\text { (var. wa) }\end{array}$ & tsha & $\mathrm{ma} / \mathrm{ma}$ \\
\hline 172 & $?, ? 8$ & $\begin{array}{l}\text { Dpal rdo rje snying po rgyan ces bya } \\
\text { ba'i rgyud kyi rgyal po chen po }\end{array}$ & tha & nya & nya / ta \\
\hline 173 & $?$ & $\begin{array}{l}\text { Dpal ye shes phreng ba'i rgyud kyi } \\
\text { rgyal po }\end{array}$ & $\begin{array}{l}\text { nga } \\
\text { (var. ga) }\end{array}$ & $\begin{array}{l}\text { ga } \\
\text { (var. kha) }\end{array}$ & $-1-$ \\
\hline 174 & $?$ & Gnod sbyin nor bu bzang po'i rtog pa & $\begin{array}{l}\text { tsha } \\
\text { (var. wa) }\end{array}$ & tsha & tsha / tsha \\
\hline
\end{tabular}

\footnotetext{
${ }^{25}$ Sloane 2837d.
} 